\title{
EVALUATION OF DOCETAXEL USE IN NON-SMALL CELL LUNG CANCER: REAL-WORLD HEALTH OUTCOMES
}

\author{
MACARENA MERINO ALMAZAN ${ }^{1 *}$, JUAN FRANCISCO MARIN POZO $^{1}, \mathrm{JUAN}$ MANUEL \\ DUARTE PEREZ ${ }^{2}$
}

\author{
${ }^{I}$ Hospital Pharmacy Department, Servicio de Farmacia Hospitalaria, Hospital Universitario de Jaén, Avda Ejército \\ Español, 10, 23007 Jaén, Spain \\ ${ }^{2}$ Pharmacology Department, Faculty of Pharmacy, University of Granada, Granada, Spain
}

*corresponding author: macarena.ma2@gmail.com

Manuscript received: November 2020

\begin{abstract}
Chemotherapy agents such as docetaxel are still used after failure of first or second-line immunotherapy. In order to establish the ideal choice of treatment, it is necessary to compare the efficacy and safety in the real-world setting between the available schemes. We performed a retrospective, observational study in a referral hospital including patients treated with docetaxel for non-small cell lung cancer between January 2013 and June 2017. Effectiveness variables included overall survival (OS) and progression free survival (PFS). The safety variable was the incidence of adverse events (AE). 91 patients were enrolled $(84.6 \%$ men) with a mean age of 63.6 years. 21 patients were treated with a combination of docetaxel + nintedanib, and the rest with monotherapy. $79.1 \%$ of patients presented AEs of any grade and treatment had to be delayed or discontinued in $10 \%$. The median PFS was 2.8 months (95\% CI 2.3-3.3) and for OS, 6.9 months (95\% CI 4.9-8.8). In adenocarcinoma patients no difference in OS was observed between monotherapy with docetaxel $v s$. docetaxel + nintedanib. Overall results are similar to clinical trials, but not when nintedanib is added to the therapy.
\end{abstract}

\section{Rezumat}

Agenții chimioterapici, cum ar fi docetaxelul, sunt încă utilizați după eșecul imunoterapiei de primă sau a doua linie. Pentru a stabili alegerea ideală a tratamentului, este necesar să se compare eficacitatea și siguranța în mediul real între schemele disponibile. A fost efectuat un studiu observațional retrospectiv într-un spital de referință, incluzând pacienți tratați cu docetaxel pentru cancer pulmonar cu celule non-mici în perioada ianuarie 2013 - iunie 2017. Variabilele de eficacitate au inclus supraviețuirea globală (OS) și supraviețuirea fără progresie (PFS). Variabila siguranță a reprezentat incidența evenimentelor adverse (AE). Au fost înrolați 91 de pacienți (84,6\% bărbați) cu o vârstă medie de 63,6 ani. 21 de pacienți au fost tratați cu o combinație de docetaxel + nintedanib, iar restul cu monoterapie. 79,1\% dintre pacienți au prezentat AE de orice grad și tratamentul a trebuit să fie întârziat sau întrerupt în $10 \%$ din cazuri. PFS mediană a fost de 2,8 luni (IC 95\% 2,33,3), iar pentru OS, 6,9 luni (IC 95\% 4,9-8,8). La pacienții cu adenocarcinom nu s-a observat nici o diferență în OS între monoterapie cu docetaxel față de docetaxel + nintedanib. Rezultatele generale sunt similare studiilor clinice, dar nu și atunci când se adaugă nintedanib la terapie.

Keywords: docetaxel, non-small cell lung cancer, real-world data, nintedanib

\section{Introduction}

Globally, lung cancer ranks first in newly diagnosed cancers and is the leading cause of cancer death worldwide [1]. 1.8 million new cases of lung cancer and almost 1.6 million deaths were estimated in 2012 . Approximately $85 \%$ of new diagnoses are from nonsmall cell lung cancer (NSCLC), and most of these patients $(70 \%)$ are diagnosed in advanced or metastatic stages [1].

The overall survival (OS) in NSCLC remains low, with an estimate of a 5-year overall survival rate of around $10-20 \%$ [2]. The prognosis depends largely on the stage at diagnosis. According to the SEER database of the National Cancer Institute, in the United States the 5-year survival rate for patients diagnosed in early stages can reach $57.4 \%$. However, only $16 \%$ of patients are diagnosed in these stages. The overall 5-year survival rate, regardless of stage, is $19.4 \%$ [3].

Until the onset of immunotherapy, docetaxel has been the standard of treatment for NSCLC in locally advanced or metastatic stages after progression to firstline chemotherapy [4]. For this reason, docetaxel was the comparator chosen in the clinical trials that resulted in the authorization of nivolumab $[5,6]$, pembrolizumab [7] and atezolizumab [8] for this indication.

Nowadays both docetaxel monotherapy [9] and the combination with nintedanib [10] are used in NSCLC patients. The docetaxel plus nintedanib scheme is only authorized for the treatment of adenocarcinoma tumour histology [10]. 
With the positioning of immunotherapy as new standard of care, not only in the second line but also the first line [11], non-immunotherapeutic drugs such as docetaxel are still needed for patients who progress after treatment with checkpoint inhibitors.

Different studies have been developed in recent years to assess the effectiveness of these drugs. For nivolumab, an OS rate of 9.1 months [95\% CI 6.6 - 11.6] and a progression free survival (PFS) rate of 4.7 months [95\% CI 3.2 - 6.2] were obtained in a multicentre study in Andalusia for NSCLC patients [12].

However, to evaluate the clinical benefit and costeffectiveness of this therapy, it is necessary to know the results of effectiveness of the reference therapy to date, docetaxel, in order to establish comparisons based on real-life data.

The years of experience with docetaxel treatment, have allowed us to have today a cohort of patients large enough to study the effectiveness and safety of treatment with this drug in the usual clinical practice. Our research is the first to provide real-world health outcomes from the use of docetaxel plus nintedanib in NSCLC. In addition, in the absence of studies at present on what would be the best treatment option for metastatic patients who progress to a treatment line based on immunotherapy, we believe it is of interest to have real-life data that can help future comparisons also in this scenario.

\section{Materials and Methods}

\section{Study design}

This is an open, retrospective, observational study developed in a referral hospital serving a population of about 640,000 people in southern Spain. The study was conducted in accordance with the Declaration of Helsinki and the Good Clinical Practice guidelines. The study protocol was approved by the Hospital Ethics Committee and the National Regulatory Agency (MAR-DOC-2018-1). As the purpose of the research was to reflect the usual clinical practice and reallife data, no financial compensation was provided to the patients or the participating physicians and no further evaluation of the study site or the patients was required.

\section{Population}

All patients who received docetaxel between January 2013 and June 2017 for the treatment of NSCLC in the hospital were included. Only patients treated with docetaxel within the context of a clinical trial were excluded.

\section{Data collection}

The data collected were obtained from the electronic medical records of the patients and from the electronic chemotherapy prescription program used in the hospital. Other sources of complementary data were laboratory records, pathology and radiology. An ad-hoc database was created for data collection.
The information gathered included demographic data of the patients (age, sex, smoking history), history of the cancer (type of tumour, date and initial stage of the disease at diagnosis, location of metastases, date of diagnosis of the advanced disease, date of progression and exitus), docetaxel-based treatment (dose, scheme, line and duration of treatment, concomitant drugs, best response to treatment), number of previous lines received and time since platinum-based therapy (TPT), adverse events (AEs) and number and duration of hospitalizations, both directly and indirectly related to docetaxel therapy.

All AEs were graded using the National Cancer Institutes-Common Terminology Criteria for Adverse Events (NCI-CTCAE) version 4.0 and were coded according to the Medical Dictionary for Regulatory Activities (MedDRA).

Effectiveness measures included PFS duration (time from the start of the initial docetaxel-containing therapy to the first recorded occurrence of physician assessed disease progression or death), OS duration (time from the start of the docetaxel-containing therapy to death) and response rate to treatment (using RECIST criteria v.1.1).

Statistical analysis

The mean, standard deviation (SD), median, range, counts and percentages (for categorical data) were calculated for the demographic and cancer characteristics. The overall incidence of AEs was summarized in terms of patient counts. PFS and OS were expressed as the median survival times, with the $95 \%$ confidence interval (CI 95\%), using the Kaplan-Meier method to estimate the survival curves; the log-rank test was used to compare the curves. The Cox proportionalhazards model was used to calculate Hazard ratios (HRs) and 95\% CIs. Statistical analyses were performed using G-Stat 2.0 software; Dep. Biometría GSK, Madrid, Spain.

\section{Results and Discussion}

A total of 91 patients with NSCLC (84.6\% men) with a mean age of 63.6 years $(\mathrm{SD}=9.5$ ) were included, $26.4 \%$ being older than 70 years. Patients' demographics and tumour characteristics are summarized in Table I. Fifty-seven patients $(62.6 \%)$ were active smokers at diagnosis. Fifty-five patients $(60.4 \%)$ had a nonsquamous histology tumour, with stage IV being the majority at diagnosis $(53.8 \%)$, followed by stage III (39.6\%). Seventy-five patients $(82.4 \%)$ had ECOG $0-1$ at the beginning of docetaxel therapy while 16 patients had ECOG 2. A significant number of patients, 21 patients (23.1\%), were observed for which docetaxel was used in combination with nintedanib. Since the addition of nintedanib to docetaxel treatment has shown an increase in OS $[13,14,16]$, the effect that such addition in terms of effectiveness could have on our population was analysed separately. At the start of 
treatment with docetaxel, all patients had progressed to locally advanced or metastatic stages. Forty-one patients $(51.9 \%)$ presented at least one metastatic location, lung and bone metastases mainly, 29 patients for each of them.
The docetaxel-containing therapy began at an average of 17.5 months $(\mathrm{SD}=16.8)$ after the start of the first line of treatment; for $22 \%$ of patients this period was less than 6 months.

Table I

Patient characteristics

\begin{tabular}{|c|c|c|}
\hline & & $\mathrm{N}^{\circ}$ patients $(\%)(\mathrm{n}=91)$ \\
\hline \multirow[t]{2}{*}{$\operatorname{Sex}(n=91)$} & Male & $77(84.6 \%)$ \\
\hline & Female & $14(15.4 \%)$ \\
\hline \multirow[t]{2}{*}{ Age $(n=91)$} & $<70$ years & $67(73.6 \%)$ \\
\hline & $>70$ years & $24(26.4 \%)$ \\
\hline \multirow[t]{2}{*}{ Smoking status $(\mathrm{n}=91)$} & Never/Former-smoker & $34(37.4 \%)$ \\
\hline & Current-smoker & $57(62.6 \%)$ \\
\hline \multirow[t]{2}{*}{ Histology $(\mathrm{n}=91)$} & Squamous & $36(39.6 \%)$ \\
\hline & Non-squamous & $55(60.4 \%)$ \\
\hline \multirow[t]{2}{*}{ ECOG $(\mathbf{n}=91)$} & $0-1$ & $75(82.4 \%)$ \\
\hline & 2 & $16(17.6 \%)$ \\
\hline \multirow[t]{4}{*}{ Stage $(n=91)$} & IV & $49(53.8 \%)$ \\
\hline & III & $36(39.6 \%)$ \\
\hline & II & $4(4.4 \%)$ \\
\hline & I & $2(2.2 \%)$ \\
\hline \multirow[t]{4}{*}{ Number of metastatic locations $(n=79)$} & 1 & $41(51.9 \%)$ \\
\hline & 2 & $26(32.9 \%)$ \\
\hline & 3 & $9(11.4 \%)$ \\
\hline & $>3$ & $3(3.8 \%)$ \\
\hline \multirow[t]{6}{*}{ Type of metastatic locations $(n=79)$} & Lung & $29(22.0 \%)$ \\
\hline & Bone & $29(22.0 \%)$ \\
\hline & Lymph nodes & $22(16.7 \%)$ \\
\hline & Liver & $15(11.4 \%)$ \\
\hline & Brain & $13(9.8 \%)$ \\
\hline & Others & $24(18.2 \%)$ \\
\hline \multirow[t]{3}{*}{ Time since platinum therapy (months) } & Mean (SD) & $17.5(16.8)$ \\
\hline & $<6$ months & $20(22.0 \%)$ \\
\hline & $>6$ months & $71(78.0 \%)$ \\
\hline \multirow[t]{2}{*}{ Treatment scheme } & Docetaxel monotherapy & $70(76.9 \%)$ \\
\hline & Docetaxel + nintedanib & $21(23.1 \%)$ \\
\hline
\end{tabular}

Patients received an average dose of docetaxel of $124.1 \mathrm{mg}(\mathrm{SD}=24.5)$ with a total average of 4.3 cycles administered $(\mathrm{SD}=3.7$, range $[1-30])$. The mean duration of the treatment was 2.9 months $(95 \%$ CI 2.2 - 3.6). Forty-two patients $(46.1 \%)$ received docetaxel as second-line treatment, 29 patients as third-line and the rest, 20 patients, as fourth or subsequent line of treatment. Eighty-seven patients (92.3\%) received platinum-based chemotherapy, 2 patients were treated with antiPD-L1 drugs, one patient with an anti-EGFR and one patient with a triplet-antiVGFR chemotherapy.

In terms of safety, $79.1 \%(n=72)$ of the patients experienced AEs of any grade related to the treatment. The therapy with docetaxel had to be delayed or discontinued in $10 \%(n=9)$ of patients due to AEs. Table II shows the incidence of AEs by type and severity.

Table II Side effects

\begin{tabular}{|lcccc|}
\hline & Any grade & \multicolumn{3}{c|}{ Delay or discontinuation } \\
\hline & $\mathrm{n}$ & $\%$ & $\mathrm{n}$ & $\%$ \\
\hline & 72 & $79.1 \%$ & 9 & $10 \%$ \\
\hline Side Effect & & & & \\
\hline Asthenia & 33 & $16.8 \%$ & 2 & $18.2 \%$ \\
\hline Others & 21 & $10.7 \%$ & 3 & $27.3 \%$ \\
\hline Diarrhoea & 16 & $8.2 \%$ & & \\
\hline Lack of appetite & 13 & $6.6 \%$ & & \\
\hline Peripheral neuropathy & 11 & $5.6 \%$ & & \\
\hline Rash & 10 & $5.1 \%$ & & \\
\hline
\end{tabular}


FARMACIA, 2021, Vol. 69, 3

\begin{tabular}{|lcccc|}
\hline & Any grade & \multicolumn{2}{c|}{ Delay or discontinuation } \\
\hline Peripheral oedema & 10 & $5.1 \%$ & & \\
\hline Stomatitis & 10 & $5.1 \%$ & 2 & $18.2 \%$ \\
\hline Nausea & 9 & $4.6 \%$ & 1 & $9.1 \%$ \\
\hline Fatigue & 8 & $4.1 \%$ & & \\
\hline Cough & 8 & $4.1 \%$ & & \\
\hline Dyspnoea & 7 & $3.6 \%$ & & \\
\hline Anaemia & 7 & $3.6 \%$ & & \\
\hline Pneumonia & 7 & $3.6 \%$ & 3 & \\
\hline Skin dryness & 6 & $3.1 \%$ & & \\
\hline Pain & 5 & $2.5 \%$ & & \\
\hline Alopecia & 4 & $2.0 \%$ & & \\
\hline Constipation & 3 & $1.5 \%$ & & \\
\hline Pruritus & 2 & $1.0 \%$ & & \\
\hline Arthralgia & 2 & $1.0 \%$ & & \\
\hline Mucosal inflammation & 1 & $0.5 \%$ & & \\
\hline Watery eyes & 1 & $0.5 \%$ & & \\
\hline Pneumonitis & 1 & $0.5 \%$ & & \\
\hline Liver enzymes elevation & 1 & $0.5 \%$ & \\
\hline
\end{tabular}

Seventeen patients (18.7\%) had some hospital admission during the course of treatment with docetaxel, with a total of 22 hospital admissions $($ mean $=1.3)$ and 182 days of hospital stay $($ mean $=10.7)$.

The PFS reached a median of 2.8 months $(95 \%$ CI 2.3 - 3.3) while the median for OS was 6.9 months
(95\% CI 4.9 - 8.8) in the total population. These values are consistent with those obtained in the phase III clinical trial that resulted in the approval of the use of docetaxel for this indication [15]. The effectiveness results obtained for all the variables are shown in Table III.

Table III

PFS and OS (total population)

\begin{tabular}{|c|c|c|c|c|c|}
\hline & \multicolumn{2}{|c|}{ PFS } & \multicolumn{2}{|c|}{ OS } \\
\hline & & $\begin{array}{c}\text { Median (m) } \\
{[\mathrm{CI} 95 \%]}\end{array}$ & $\begin{array}{c}\mathrm{p} \\
\text { (log rank) }\end{array}$ & $\begin{array}{c}\text { Median (m) } \\
{[\mathrm{CI} 95 \%]}\end{array}$ & $\begin{array}{c}\mathrm{p} \\
(\log \text { rank })\end{array}$ \\
\hline \multicolumn{2}{|c|}{ Population $(\mathrm{n}=91)$} & $\begin{array}{c}2.8 \\
{[2.3-3.3]}\end{array}$ & - & $\begin{array}{c}6.9 \\
{[4.9-8.7]}\end{array}$ & - \\
\hline \multirow[t]{2}{*}{ Sex } & Male & $\begin{array}{c}2.6 \\
{[2.1-3.2]}\end{array}$ & \multirow{2}{*}{0.237} & $\begin{array}{c}6.9 \\
{[5.4-8.3]}\end{array}$ & \multirow{2}{*}{0.293} \\
\hline & Female & $\begin{array}{c}4.0 \\
{[1.6-6.3]}\end{array}$ & & $\begin{array}{c}5.2 \\
{[0-10.3]}\end{array}$ & \\
\hline \multirow[t]{2}{*}{ Age } & $<70$ years & $\begin{array}{c}2.8 \\
{[2.2-3.4]}\end{array}$ & \multirow{2}{*}{0.757} & $\begin{array}{c}9.7 \\
{[6.9-12.5]}\end{array}$ & \multirow{2}{*}{0.821} \\
\hline & $>70$ years & $\begin{array}{c}2.7 \\
{[1.9-3.5]}\end{array}$ & & $\begin{array}{c}12.8 \\
{[3.4-22.3]}\end{array}$ & \\
\hline \multirow[t]{2}{*}{ Histology } & Squamous & $\begin{array}{c}2.2 \\
{[1.9-2.3]}\end{array}$ & \multirow{2}{*}{0.011} & $\begin{array}{c}3.1 \\
{[1.7-4.4]}\end{array}$ & \multirow{2}{*}{0.048} \\
\hline & Non-squamous & $\begin{array}{c}3.5 \\
{[2.6-4.5]}\end{array}$ & & $\begin{array}{c}7.8 \\
{[6.2-9.3]}\end{array}$ & \\
\hline \multirow[t]{2}{*}{ ECOG } & $0-1$ & $\begin{array}{c}2.9 \\
{[2.3-3.6]}\end{array}$ & \multirow{2}{*}{$<0.0001$} & $\begin{array}{c}7.8 \\
{[6.5-9.1]}\end{array}$ & \multirow{2}{*}{$<0.0001$} \\
\hline & 2 & $\begin{array}{c}1.3 \\
{[0-2.7]}\end{array}$ & & $\begin{array}{c}0.7 \\
{[0-1.9]}\end{array}$ & \\
\hline \multirow[t]{2}{*}{ TPT } & $<6$ months & $\begin{array}{c}2.4 \\
{[1.7-3.0]}\end{array}$ & \multirow{2}{*}{0.464} & $\begin{array}{c}2.3 \\
{[0.4-4.3]}\end{array}$ & \multirow{2}{*}{0.091} \\
\hline & $>6$ months & $\begin{array}{c}3.0 \\
{[2.5-3.4]}\end{array}$ & & $\begin{array}{c}7.2 \\
{[5.4-9.0]}\end{array}$ & \\
\hline
\end{tabular}

Overall, significantly larger PFS medians have been observed in patients with non-squamous versus squamous histology tumours (3.5 months vs. 2.2 months, respectively, $\mathrm{p}=0.011$ ) and in patients with ECOG $0-1 v s$. ECOG 2 (2.9 months vs. 1.3 months, respectively, $\mathrm{p}<0.0001)$. The medians of OS have also been statistically superior in the same groups.

The response to treatment was one complete response, 13 patients with partial response $(14.3 \%)$ and 18 
FARMACIA, 2021, Vol. 69, 3

patients achieved disease stabilization (19.8\%). Thirtyfive patients $(38.5 \%)$ did not respond to treatment. Information regarding the response was not available in 23 patients.

In the group of patients treated with docetaxel monotherapy (Table IV), a significant difference has been obtained in both PFS and OS, depending on the ECOG of the patients, being favourable for the group of patients with ECOG $0-1$ compared to patients with ECOG 2 (2.8 months vs. 0.7 months, respectively, $\mathrm{p}<0.0001$ for SLP and 7.2 months $v s .0 .7$ months, respectively, $\mathrm{p}<0.0001$ for the OS). However, the difference observed based on histology in the global population has not been obtained in this group, which could suggest that this difference could be due to a possible added benefit from the use of nintedanib in patients with adenocarcinoma.

Table IV

PFS and OS (docetaxel monotherapy)

\begin{tabular}{|c|c|c|c|c|c|c|c|}
\hline & \multicolumn{3}{|c|}{ PFS } & \multicolumn{3}{|c|}{ OS } \\
\hline & & $\begin{array}{c}\text { Median (m) } \\
{[\mathrm{CI} 95 \%]}\end{array}$ & $\begin{array}{c}\mathrm{p} \\
\text { (log rank) }\end{array}$ & HR & $\begin{array}{c}\text { Median (m) } \\
\text { [CI 95\%] }\end{array}$ & $\begin{array}{c}\mathrm{p} \\
\text { (log rank) }\end{array}$ & HR \\
\hline \multicolumn{2}{|c|}{ Population $(\mathrm{n}=70)$} & $\begin{array}{c}2.4 \\
{[1.8-2.9]}\end{array}$ & - & - & $\begin{array}{c}5.7 \\
{[3.1-8.2]}\end{array}$ & - & \\
\hline \multirow[t]{2}{*}{ Sex } & Male & $\begin{array}{c}2.2 \\
{[1.9-2.5]}\end{array}$ & \multirow{2}{*}{0.220} & \multirow{2}{*}{$\begin{array}{c}0.71 \\
{[0.3-1.9]}\end{array}$} & $\begin{array}{c}6.3 \\
{[3.5-9.1]}\end{array}$ & \multirow{2}{*}{0.298} & \multirow{2}{*}{$\begin{array}{c}0.88 \\
{[0.4-1.9]}\end{array}$} \\
\hline & Female & $\begin{array}{c}2.9 \\
{[2.1-3.8]}\end{array}$ & & & $\begin{array}{c}5.2 \\
{[2.9-7.4]}\end{array}$ & & \\
\hline \multirow[t]{2}{*}{ Age } & $<70$ years & $\begin{array}{c}2.4 \\
{[1.9-2.8]}\end{array}$ & \multirow{2}{*}{0.676} & \multirow{2}{*}{$\begin{array}{c}0.98 \\
{[0.9-1.0]}\end{array}$} & $\begin{array}{c}5.5 \\
{[3.2-7.8]}\end{array}$ & \multirow{2}{*}{0.188} & \multirow{2}{*}{$\begin{array}{c}0.99 \\
{[0.9-1.0]}\end{array}$} \\
\hline & $>70$ years & $\begin{array}{c}2.2 \\
{[1.5-2.9]}\end{array}$ & & & $\begin{array}{c}6.9 \\
{[4.9-8.9]}\end{array}$ & & \\
\hline \multirow[t]{2}{*}{ Histology } & Squamous & $\begin{array}{c}2.2 \\
{[1.9-2.3]}\end{array}$ & \multirow{2}{*}{0.164} & \multirow{2}{*}{$\begin{array}{c}0.62 \\
{[0.4-1.1]}\end{array}$} & $\begin{array}{c}3.1 \\
{[1.7-4.4]}\end{array}$ & \multirow{2}{*}{0.242} & \multirow{2}{*}{$\begin{array}{c}0.59 \\
{[0.3-1.0]}\end{array}$} \\
\hline & Non-squamous & $\begin{array}{c}2.8 \\
{[1.8-3.8]}\end{array}$ & & & $\begin{array}{c}6.9 \\
{[5.1-8.6]}\end{array}$ & & \\
\hline \multirow[t]{2}{*}{ ECOG } & $0-1$ & $\begin{array}{c}2.8 \\
{[2.3-3.3]}\end{array}$ & \multirow{2}{*}{$<0.0001$} & \multirow{2}{*}{$\begin{array}{c}3.8 \\
{[1.9-7.5]}\end{array}$} & $\begin{array}{c}7.2 \\
{[5.2-9.2]}\end{array}$ & \multirow{2}{*}{$<0.0001$} & \multirow{2}{*}{$\begin{array}{c}3.9 \\
{[2.1-7.4]}\end{array}$} \\
\hline & 2 & $\begin{array}{c}0.7 \\
{[0-1.7]}\end{array}$ & & & $\begin{array}{c}0.7 \\
{[0-1.7]}\end{array}$ & & \\
\hline \multirow[t]{2}{*}{ TPT } & $<6$ months & $\begin{array}{c}1.4 \\
{[0-4.0]}\end{array}$ & \multirow{2}{*}{0.084} & \multirow{2}{*}{$\begin{array}{c}1.01 \\
{[0.9-1.03]}\end{array}$} & $\begin{array}{c}2.1 \\
{[0.7-3.6]}\end{array}$ & \multirow{2}{*}{$<0.0001$} & \multirow{2}{*}{$\begin{array}{c}1.01 \\
{[0.9-1.03]}\end{array}$} \\
\hline & $>6$ months & $\begin{array}{c}2.7 \\
{[2.0-3.4]}\end{array}$ & & & $\begin{array}{c}6.9 \\
{[4.6-9.1]}\end{array}$ & & \\
\hline
\end{tabular}

The results of the analysis performed with the data of adenocarcinoma patients treated with docetaxel monotherapy $v s$. docetaxel associated with nintedanib (Table V) partially corroborates the previous hypothesis, since the PFS rate is significantly higher in patients with docetaxel + nintedanib than in patients with docetaxel monotherapy (4.7 months vs. 2.8 months, respectively, $\mathrm{p}=0.038$ ).

Table V

PFS and OS (adenocarcinoma)

\begin{tabular}{|c|c|c|c|c|c|c|}
\hline & \multicolumn{3}{|c|}{ PFS } & \multicolumn{3}{c|}{ OS } \\
\cline { 2 - 7 } & $\begin{array}{c}\text { Median (m) } \\
{[\text { CI 95\%] }}\end{array}$ & $\begin{array}{c}\mathrm{p} \\
(\log \text { rank })\end{array}$ & HR & $\begin{array}{c}\text { Median (m) } \\
{[\text { CI 95\%] }}\end{array}$ & $\begin{array}{c}\mathrm{p} \\
(\log \text { rank })\end{array}$ & HR \\
\hline $\begin{array}{c}\text { Docetaxel monotherapy } \\
(\mathrm{n}=34)\end{array}$ & $\begin{array}{c}2.8 \\
{[1.8-3.8]}\end{array}$ & 0.038 & $\begin{array}{c}6.51 \\
{[0.3-0.98]}\end{array}$ & $\begin{array}{c}8.4 \\
{[5.1-8.6]}\end{array}$ & 0.08 & 0.59 \\
\hline $\begin{array}{c}\text { Docetaxel + nintedanib } \\
(\mathrm{n}=21)\end{array}$ & $\begin{array}{c}4.7 \\
{[4.0-5.4]}\end{array}$ & & $0.3-1.1]$ \\
\hline
\end{tabular}

On the contrary, this difference is not observed when we analyse the OS rates (6.9 months vs. 8.3 months, respectively, $\mathrm{p}=0.08$ ). These results differ from those obtained in the LUME-LUNG 1 clinical trial [13] in which the OS was in fact significantly higher for the group treated with nintedanib and with adeno- carcinoma histology. It must be pointed out that, in our study, the number of patients with 2 or more previous lines of treatment was lower in the nintedanib group (57.1\% vs. $42.8 \%$, respectively), therefore we cannot consider that this factor has contributed to the result of no difference in OS; neither it can be 
attributed to the existence of a greater number of patients with ECOG 2 in the nintedanib group since it is the docetaxel-monotherapy group that presents a greater number of these patients $(20.6 \%$ vs. $4.8 \%$, respectively).

\section{Conclusions}

Globally, the use of docetaxel for NSCLC brings consistent results, in terms of effectiveness and safety, in real clinical practice compared to the ones obtained in the authorization clinical trials. Discrepancies with the clinical trials are found when we compare the results of patients with adenocarcinoma treated with docetaxel monotherapy $v s$. docetaxel + nintedanib. In this case, the OS rate is not different for the two groups. Considering that the addition of nintedanib implies a high increase in treatment costs and with the absence of benefit in OS, future evaluations should be made in order to assess whether the addition of nintedanib really represents an efficient therapy for the Health System.

\section{Conflict of interest}

The authors declare no conflict of interest.

\section{References}

1. Ferlay J, Soerjomataram I, Dikshit R, Eser S, Mathers C, Rebelo M, Parkin DM, Forman D, Bray F, Cancer incidence and mortality worldwide: Sources, methods and major patterns in GLOBOCAN 2012: Globocan 2012. Int J Cancer, 2015; 136(5): e359-386.

2. Davies J, Patel M, Gridelli C, de Marinis F, Waterkamp D, McCusker ME, Real-world treatment patterns for patients receiving second-line and thirdline treatment for advanced non-small cell lung cancer: A systematic review of recently published studies. PLoS One, 2017; 12(4): e0175679: 1-19.

3. SEER. Cancer of the Lung and Bronchus - Cancer Stat Facts, https://seer.cancer.gov.

4. Novello S, Barlesi F, Califano R, Cufer T, Ekman S, Levra MG, Kerr K, Popat S, Reck M, Senan S, Simo GV, Vansteenkiste J, Peters S, Metastatic non-small-cell lung cancer: ESMO Clinical Practice Guidelines for diagnosis, treatment and follow-up. Ann Oncol., 2016; 27(suppl_5): v1-27.

5. Borghaei H, Paz-Ares L, Horn L, Spigel DR, Steins M, Ready NE, Chow LQ, Vokes EE, Felip E, Holgado E, Barlesi F, Kohlhäufl M, Arrieta O, Burgio MA, Fayette J, Lena H, Poddubskaya E, Gerber DE, Gettinger SN, Rudin CM, Rizvi N, Crinò L, Blumenschein GR, Antonia SJ, Dorange C, Harbison CT, Finckenstein FG, Brahmer JR, Nivolumab versus Docetaxel in Advanced Non-squamous Nonsmall Cell Lung Cancer. $N$ Engl J Med., 2015; 373(17): 1627-1639.

6. Brahmer J, Reckamp KL, Baas P, Crinò L, Eberhardt WEE, Poddubskaya E, Scott A, Pluzanski A, Vokes EE, Holgado E, Waterhouse D, Ready N, Gainor J, Arén Frontera O, Havel L, Steins M, Garassino MC, Aerts JG, Domine M, Paz-Ares L, Reck M, Baudelet
C, Harbison CT, Lestini B, Spiegel DR, Nivolumab versus Docetaxel in Advanced Squamous-Cell Non-Small-Cell Lung Cancer. $N$ Engl J Med., 2015; 373(2): 123-135.

7. Herbst RS, Baas P, Kim DW, Felip E, Pérez-Gracia JL, Han JY, Molina J, Kim JH, Dubos Arvis C, Ahn MJ, Majem M, Fidler MJ, de Castro Jr G, Garrido M, Lubiniecki GM, Shentu Y, Im E, Dolled-Filhart $\mathrm{M}$, Garon EB, Pembrolizumab versus docetaxel for previously treated, PD-L1-positive, advanced nonsmall-cell lung cancer (KEYNOTE-010): a randomised controlled trial. Lancet, 2016; 387(10027): 15401550.

8. Rittmeyer A, Barlesi F, Waterkamp D, Park K, Ciardiello F, von Pawel J, Gadgeel SM, Hida T, Kowalski DM, Cobo Dols M, Cortinovis DL, Leach J, Polikoff J, Barrios C, Kabbinavar F, Arén Frontera O, De Marinis F, Turna H, Lee JS, Ballinger M, Kowanetz M, He P, Chen DS, Sandler A, Gandara DR, Atezolizumab versus docetaxel in patients with previously treated non-small-cell lung cancer (OAK): a phase 3, open-label, multicentre, randomised controlled trial. Lancet, 2017; 389(10066): 255-265.

9. National Comprehensive Cancer Network. NCCN Clinical Practice Guidelines in Oncology (NCCN Guidelines ${ }^{\circledR}$ ) Non-Small Cell Lung Cancer (ver. 7.2019), www.nccn.org.

10. European Medicines Agency. Vargatef ${ }^{\circledR}$ Summary of Product Characteristics. European Medicines Agency, www.ema.europa.eu.

11. Planchard D, Popat S, Kerr K, Novello S, Smit EF, Faivre-Finn C, Mock TS, Reck M, Van Schil PE, Hellmann MD, Peters S, Metastatic non-small cell lung cancer: ESMO Clinical Practice Guidelines for diagnosis, treatment and follow-up $\dagger$. Ann Oncol., 2018; 29(Suppl_4): iv192-237.

12. Merino Almazán M, Duarte Pérez JM, Marín Pozo JF, Ortega Granados AL, Muros De Fuentes B, Quesada Sanz P, Gago Sánchez AI, Rodríguez Gómez P, Jurado García JM, Artime RodríguezHermida F, Martínez Bautista MJ, Rueda Ramos A, Mora Rodríguez B, Martínez Díaz MC, Nieto Guindo P, Garrido Siles M, Villatoro Roldán R, Roldán Morales JC, Artacho Criado SM, Baños Roldán U, Inoriza Rueda A, Garrido Martínez MT, A multicentre observational study of the effectiveness, safety and economic impact of nivolumab on nonsmall-cell lung cancer in real clinical practice. Int $J$ Clin Pharm., 2019; 41(1): 272-279.

13. Reck M, Kaiser R, Mellemgaard A, Douillard J-Y, Orlov S, Krzakowski M, von Pawel J, Gottfried M, Bondarenko I, Liao M, Gann CN, Barrueco J, GaschlerMarkefski B, Novello S, Docetaxel plus nintedanib versus docetaxel plus placebo in patients with previously treated non-small-cell lung cancer (LUMELung 1): a phase 3, double-blind, randomised controlled trial. The Lancet Oncology, 2014; 15(2): 143-155.

14. Gottfried M, Bennouna J, Bondarenko I, Douillard JY, Heigener DF, Krzakowski M, Mellemgaard A, Novello S, Orlov S, Summers Y, von Pawel J, Stöhr J, Kaiser R, Reck M, Efficacy and Safety of Nintedanib Plus Docetaxel in Patients with Advanced 
FARMACIA, 2021, Vol. 69, 3

Lung Adenocarcinoma: Complementary and Exploratory Analyses of the Phase III LUME-Lung 1 Study. Target Oncol., 2017; 12(4): 475-485.

15. European Medicines Agency. Taxotere ${ }^{\circledR}$ Summary of Product Characteristics, www.ema.europa.eu
16. Espinosa Bosch M, Asensi Diez R, García Agudo S, Clopés Estela A, Nintedanib in previously untreated non-small cell lung cancer patients (available in Spanish). SEFH (ed.). 2015; gruposdetrabajo.sefh.es. 